\title{
From partner choice to equity - and beyond?
}

\section{Citation}

Warneken, Felix. 2013. "From Partner Choice to Equity - and Beyond?" Behavioral Brain Sciences 36 (01) (February): 102.

\section{Published Version}

doi:10.1017/S0140525X12000891

\section{Permanent link}

http://nrs.harvard.edu/urn-3:HUL.InstRepos:12286880

\section{Terms of Use}

This article was downloaded from Harvard University's DASH repository, and is made available under the terms and conditions applicable to Open Access Policy Articles, as set forth at http:// nrs.harvard.edu/urn-3:HUL.InstRepos:dash.current.terms-of-use\#OAP

\section{Share Your Story}

The Harvard community has made this article openly available.

Please share how this access benefits you. Submit a story.

Accessibility 
$<\mathrm{RH}>$ Commentary/Baumard et al.: A mutualistic approach to morality

$<\mathrm{CT}>$ From partner choice to equity - and beyond?

$<$ CA $>$ Felix Warneken

<CAA > Department of Psychology, Harvard University, Cambridge, MA 02138. warneken@wjh.harvard.edu

\section{https://software.rc.fas.harvard.edu/lds/research/warneken/warneken}

$<\mathrm{C}-\mathrm{AB}>$ Abstract: Baumard et al. provide an intriguing model where morality emerges from the dynamics of partner choice in mutualistic interactions. I discuss evidence from human and nonhuman primates that supports the overall approach, but highlights a gap in explaining the human specificity of moral cognition. I suggest that an essential characteristic of human fairness is to override concerns about merit in favor of promoting the welfare in others who are needy.

$<$ C-Text begins $>$

A major claim underpinning the approach taken by Baumard and colleagues is that partner choice (in which social agents choose mutualistic partners and advertise their cooperativeness) plays a critical role in the emergence of human cooperation and fairness. In particular, partner choice may be more important than partner control (in which agents decide whether to cooperate or defect in a dyadic situation). These claims mainly derive from data with human adults. However, given that this moral sense is supposed to be unique to our species, it is important to understand the evolutionary changes and ontogenetic origins of these behaviors, as well.

In fact, evidence from both human children and other species suggests that partner choice is a fundamental mechanism shaping cooperation both across ontogeny and in 
other species. In nonhuman primates, observational and experimental studies provide abundant evidence that individuals engage in long-term reciprocal relationships that result from seeking out other cooperators (Schino \& Aureli 2010). For example, chimpanzees selectively choose skillful over unskillful cooperators for a mutualistic task (Melis et al. 2006) and choose a partner who had chosen them previously over one who ignored them (Melis et al. 2008). In contrast, evidence for reciprocal exchanges in which individuals temporally modulate their cooperation within a dyad contingent upon the partner's prior behavior (such as tit-for-tat) is weak to nonexistent (Hammerstein 2003). In human infants, a similar pattern has emerged. In the first few years of life, children begin to differentiate between cooperators and defectors (Kuhlmeier et al. 2003), show a preference for cooperators over defectors (Hamlin et al. 2007), and tend to cooperate with cooperators over defectors (Dunfield \& Kuhlmeier 2010). However, temporally contingent reciprocity in a dyadic relationship seems to emerge much later: Children do not begin to selectively decrease or increase their giving in response to what they received from a partner until 3.5 years of age (Warneken \& Tomasello 2009).

Together, these data suggest that both nonhuman and human primates might be better equipped for partner choice than for partner control. On the one hand, this seems to support the claim by Baumard et al. that partner choice is an important mechanism supporting cooperative activities more generally. However, this also raises a major challenge to this model's explanatory power in illuminating human cooperation and morality more specifically. If nonhuman primates also engage in mutually beneficial interactions and seek out other good cooperators, why does this not scale up to a "fullfledged moral sense" (sect. 4, para. 2) characterizing humans? Thus, while morality may 
be a "consequence" of mutualistic cooperation that includes social selection, this seems unlikely to be the full story, given these comparative and developmental findings. In general, this suggests that some other factors are necessary to explain humanlike morality beyond mutualism and partner choice.

What might account for the emergence of the moral systems that we see in humans? I suggest that one relevant feature is the coupling of fairness norms with concerns for other people's welfare. As Baumard et al. suggest, merit-based principles (based on assessments of work contributions) might emerge from the dynamics of selecting partners and divvying up the resulting benefit of mutualistic interactions. However, this does not appear to account for distributive justice more broadly construed. That is, moral considerations in the domain of resource sharing are not restricted to merit alone, but also can be used to improve the situation of disadvantaged individuals. This distinction is already important in the domain of mutually beneficial cooperative interactions that are the focus here. In addition, they become crucial in situations in which individuals must decide whether to share resources with unrelated individuals who are prevented from engaging in such mutualistic interactions in the first place. Prescriptive theories of justice try to account for this situation. For example, Rawls' difference principle suggests that not everything should be left to talent and effort: Inequalities are permissible if they accrue benefit to the disadvantaged (Rawls 1971). Moreover, descriptive models of adult behavior suggest that people's reasoning and behavior concern not only equitable distributions, but also involve adjustments based upon others need (Deutsch 1975). Such processes where fair distributions account for other's needs, moreover, are often fueled by empathy and sympathy with the welfare of others 
(Hoffman 2000). Along these lines, developmental studies indicate that children progress through a developmental sequence reflecting the integration of these different principles: Younger children focus on strict equality and individual work contributions, but older children make need-based adjustments (Damon 1977). In conclusion, it seems that the essence of genuinely moral behavior in humans is to partly override mutualistic strategism, which poses a challenge for the current model to integrate this characteristic of human behavior.

$<$ C-Text ends $>$

$<$ ACK $>$ ACKNOWLEDGMENTS

I thank Alexandra Rosati for helpful comments.

$<$ RFT $>$ References [Felix Warneken]

$<$ REFS >

Damon, W. (1977) The social world of the child. Jossey-Bass.

Deutsch, M. (1975) Equity, equality, and need: What determines which value will be used as the basis of distributive justice. Journal of Social Issues 31:137-49.

Dunfield, K. A. \& Kuhlmeier, V. A. (2010) Intention-mediated selective helping in infancy. Psychological Science 21(4):523-27.

Hamlin, K. J., Wynn, K. \& Bloom, P. (2007) Social evaluation by preverbal infants. Nature 450:557-60.

Hammerstein, P. (2003) Why is reciprocity so rare in social animals? A protestant appeal. In: Genetic and cultural evolution of cooperation, ed. P. Hammerstein. MIT Press. 
Hoffman, M. L. (2000) Empathy and moral development: Implications for caring and justice. Cambridge University Press.

Kuhlmeier, V., Wynn, K. \& Bloom, P. (2003) Attribution of dispositional states by 12month-olds. Psychological Science 14(5):402-8.

Melis, A. P., Hare, B. \& Tomasello, M. (2006) Chimpanzees recruit the best collaborators. Science 311:1297-300.

Melis, A. P., Hare, B. \& Tomasello, M. (2008) Do chimpanzees reciprocate received favours? Animal Behaviour 76(3):951-62.

Rawls, J. (1971) A theory of justice. Belknap Press of Harvard University Press.

Schino, G. \& Aureli, F. (2010) Primate reciprocity and its cognitive requirements. Evolutionary Anthropology 19:130-35.

Warneken, F. \& Tomasello, M. (2009) Reciprocal helping and sharing in young children. Poster presented at the Biennial Meeting of the Society for Research in Child Development, Denver, CO.

$<$ REFS END $>$ 